\title{
Oxidative stress response of rainbow trout (Oncorhynchus mykiss) to multiple stressors
}

\author{
Radovan Kopp ${ }^{1}$, Miroslava Palíková2, Ivana Papežíkováa ${ }^{2}$ Jan Mareš ${ }^{1}$, Stanislav Navrátil$^{2}$, \\ Jiří Pikula ${ }^{2}$, Miroslav Pohanka ${ }^{3}$ \\ ${ }^{1}$ Mendel University in Brno, Faculty of AgriSciences, Department of Fisheries and Hydrobiology, \\ Brno, Czech Republic \\ ${ }^{2}$ University of Veterinary and Pharmaceutical Sciences Brno, Faculty of Veterinary Hygiene and Ecology, \\ Department of Ecology and Diseases of Game, Fish and Bees, Brno, Czech Republic \\ ${ }^{3}$ University of Defence, Faculty of Military Health Sciences, Centre of Advanced Studies, \\ Hradec Kralove, Czech Republic
}

Received May 3, 2017

Accepted April 3, 2018

\begin{abstract}
Fish can be exposed to multiple stressors at the same time, including natural toxins, environmental pollutants or feed contamination. In this study, we report on the effects of controlled exposure of rainbow trout (Oncorhynchus mykiss) to multiple stressors. In doing so, we test the hypothesis that cyanobacterial biomass and arsenic in feed combine to enhance negative effects on fish, including modulation of antioxidant response. The trout (mean weight $288 \pm 59 \mathrm{~g}$ ) were divided into six experimental groups of 25 fish each (C - control group; B $3 \%$ lyophilised toxic cyanobacterial biomass; As5 - arsenic at $5 \mathrm{mg} \cdot \mathrm{kg}^{-1}$; As50 - arsenic at 50 $\mathrm{mg} \cdot \mathrm{kg}^{-1}$; and two combinations of cyanobacterial biomass and arsenic (B+As5 and $\mathrm{B}+\mathrm{As} 50$ ). All indicators of oxidative stress were determined using standard methods, showing significant changes. Overall antioxidant capacity (ferric reducing antioxidant power) decreased significantly in the liver, gills and heart after 10-days, while lipid peroxidation (thiobarbituric acid reactive substances) increased in the liver of groups exposed to cyanobacterial biomass, and in the heart of groups exposed to increased concentrations of arsenic and those under combined exposure. Levels of glutathione reductase showed a significant reduction following exposure, especially in the gills and liver. Our results indicate that the antioxidant system plays an important role in the protective response of tissues to stressors, and especially arsenic.
\end{abstract}

Fish, arsenic, microcystin, FRAP, TBARS, GR

Arsenic is one of the most toxic of environmental contaminants. Arsenic is readily accumulated in the tissues of fish and other organisms (Celechovska et al. 2011). As such, fish are valuable bioindicators of arsenic toxicity as they are continuously exposed to the contaminant through gill respiration and intake of arsenic in contaminated food (Ghosh et al. 2006). Many studies have also examined sub-lethal effects of exposure, such as growth reduction, avoidance behaviour, and haematological, biochemical and ionoregulatory responses (Lavanya et al. 2011). Freshwater fish can be exposed to high doses of arsenic when fed commercial feed mixtures containing marine fish meal. In the Czech Republic, the arsenic content in complete fish feed is limited to $6 \mathrm{mg} \cdot \mathrm{kg}^{-1}$ under Czech Decree No. 356/2008 on animal feedstuffs.

Cyanobacteria are world-wide occurring natural components of marine and freshwater ecosystems. Cyanobacteria and fish have coevolved in the same habitats; hence, the question arises as to whether the cyanotoxins in cyanobacteria taken naturally as a component of the fish diet affect fish physiology (e.g. growth) and accumulate in the fish body. A number of studies have examined the influence of cyanotoxins either experimentally or following

Address for correspondence:

Assoc. Prof. Radovan Kopp, Ph.D.

Department of Fisheries and Hydrobiology

Faculty of AgriSciences, Mendel University in Brno

Zemědělská 1, 61300 Brno, Czech Republic 
natural contamination using a range of clinical, morphological, histological, ultrastructural, haematological, and biochemical methods (Paskerova et al. 2012).

One of the most common by-products of cyanobacterial blooms are hepatotoxic microcystins (Microcystis), which can occur at high concentrations in shallow waters where cyanobacteria accumulate. Consumption of microcystins along with the cyanobacteria can result in injuries to fish. Microcystins are also released into the water following the death and decay of cyanobacterial biomass, after which they can enter the fish body through the gills. A complete summary on the effects of microcystins on fish has been published by Malbrouck and Kestemont (2006).

Under natural conditions, fish are often exposed to multiple stressors, including both natural toxins and chemical pollutants. Synergistic interactions between chemical and natural stressors complicate the ecological risk assessment of chemical mixtures considerably. Despite this, interactions with cyanobacterial stressors have received very little attention thus far (Cerbin et al. 2010; de Coninck et al. 2013).

In this study, we examine the effects of controlled exposure of multiple stressors (arsenic and cyanobacteria) on a test fish, the rainbow trout (Oncorhynchus mykiss) using a range of oxidative stress indicators. In doing so, our aim was to test the hypothesis that the effects of cyanobacterial biomass in feed and a feed contaminant (represented by arsenic) are increased when taken in combination.

\section{Materials and Methods}

All rainbow trout (mean weight $288 \pm 59 \mathrm{~g}$ ) in this experiment were obtained from the Skalní Mlýn commercial fish farm in the Czech Republic. The fish were left to acclimatise for 20 days prior to the start of the experiment. The trout were divided into six experimental groups of 25 fish each, with each group being placed into individual $1 \mathrm{~m}^{3}$ tanks with their own recirculation system. These tanks were kept under controlled light (12-h light/12-h dark) and temperature conditions throughout the experiment.

Water temperature, $\mathrm{pH}$, oxygen saturation and conductivity were monitored every day. Water properties during the experiment were as follows (for the control and experimental groups, respectively): water temperature $16.4 \pm 0.3 / 15.4 \pm 0.3{ }^{\circ} \mathrm{C}$; dissolved oxygen $-91.5 \pm 4.2 / 91.7 \pm 3.6 \%$; $\mathrm{pH}-8.2 \pm 0.2 / 8.3 \pm 0.1$; conductivity (recalculated to $25^{\circ} \mathrm{C}$ ) $-70.5 \pm 9.8 / 70.9 \pm 9.6 \mathrm{mS} \cdot \mathrm{m}^{-1}$. Oxygen saturation, $\mathrm{pH}$ and temperature were measured using a HACH HQ40D portable meter (HACH LANGE, Germany). Conductivity measurements were taken using a HANNA HI 98129 conductivity meter (HANNA Instruments, USA).

Chemical properties (nitrite nitrogen $\left[\mathrm{N}-\mathrm{NO}_{2}\right]$, nitrate nitrogen $\left[\mathrm{N}-\mathrm{NO}_{3}\right]$, ammonia nitrogen $\left[\mathrm{N}-\mathrm{NH}_{4}\right]$ and phosphate phosphorus $\left[\mathrm{P}-\mathrm{PO}_{4}\right]$ ) were determined each week using standard methods (APHA 1998). Properties during the experiment were as follows (for the control and experimental groups, respectively): $\mathrm{N}-\mathrm{NH}_{4} 0.05 \pm 0.04 / 0.04 \pm 0.04 \mathrm{mg} \cdot 1^{-1} ; \mathrm{N}_{-N_{3}} 24.3 \pm 2.3 / 24.2 \pm 2.1 \mathrm{mg} \cdot 1^{-1} ; \mathrm{N}^{-\mathrm{NO}_{2}} 0.12 \pm 0.09 / 0.13 \pm 0.10 \mathrm{mg} \cdot 1^{-1} ;$ $\mathrm{P}_{-} \mathrm{PO}_{4} 0.66 \pm 0.04 / 0.62 \pm 0.16 \mathrm{mg} \cdot \mathrm{l}^{-1}$.

The control group (C) was fed with EFICO Enviro 920 commercial complete food (Biomar, Denmark; 44\% proteins, $29 \%$ fat, $12.4 \%$ nitrogen free extract, gross energy $25 \mathrm{MJ} \cdot \mathrm{kg}^{-1}$ ), which contained arsenic at trace levels $\left(1.55 \mathrm{mg} \cdot \mathrm{kg}^{-1}\right)$ below the maximum allowable limits. Each of the five experimental groups received the same food; with the addition of 3\% lyophilised toxic cyanobacterial biomass (Group B); arsenic at $5 \mathrm{mg} \cdot \mathrm{kg}^{-1}$ (Group As5); arsenic at $50 \mathrm{mg} \cdot \mathrm{kg}^{-1}$ (Group As50); and two combinations of cyanobacterial biomass and arsenic (Groups $\mathrm{B}+\mathrm{As} 5$ and B + As50). Fish were fed twice a day for 30 days at $0.8 \%$ of the fish weight for the first 10 days and then at $1 \%$ of the fish weight for the following 20 days.

Cyanobacterial biomass (identified microscopically as a monoculture species of Microcystis aeruginosa; 43.3\% proteins, $2.3 \%$ fat) was obtained from ponds at the Pohořelice fish farm in the Czech Republic. The cyanobacteria were lyophilised and stored at $-20{ }^{\circ} \mathrm{C}$ until required. Microcystin concentration was measured using a modified liquid chromatography with tandem mass spectrometry (LC-MS/MS) method according to Kohoutek et al. (2010). The microcystins present were identified as MC-RR (1462.4 $\left.\mu \mathrm{g} \cdot \mathrm{g}^{-1} \mathrm{DW}\right), \mathrm{MC}-\mathrm{LR}$ (1087.9 $\left.\mu \mathrm{g} \cdot \mathrm{g}^{-1} \mathrm{DW}\right), \mathrm{MC}$ YR $\left(95.9 \mu \mathrm{g} \cdot \mathrm{g}^{-1} \mathrm{DW}\right)$ and unidentified $\left(51.7 \mu \mathrm{g} \cdot \mathrm{g}^{-1} \mathrm{DW}\right)$. Total microcystin concentration was $2697.9 \mu \mathrm{g} \cdot \mathrm{g}^{-1} \mathrm{DW}$; hence, $3 \%$ of cyanobacterial biomass added to the feed corresponded to $81 \mathrm{mg} \mathrm{MCs} \cdot \mathrm{kg}^{-1}$ feed. A standardised arsenic solution (Astasol, Analytika Praha, Czech Republic) was used for the preparation of arsenic-contaminated food, with the stock solution containing $1.000 \pm 0.002 \mathrm{~g} \cdot 1^{-1}$ $\mathrm{As}^{5+}$ in $2 \%$ nitric acid.

Seven fish from each group were sampled after 10, 20 and 30 days of exposure. The fish were sacrificed by stunning with a blow to the back of the head followed by spinal cord transection. Each fish was dissected 

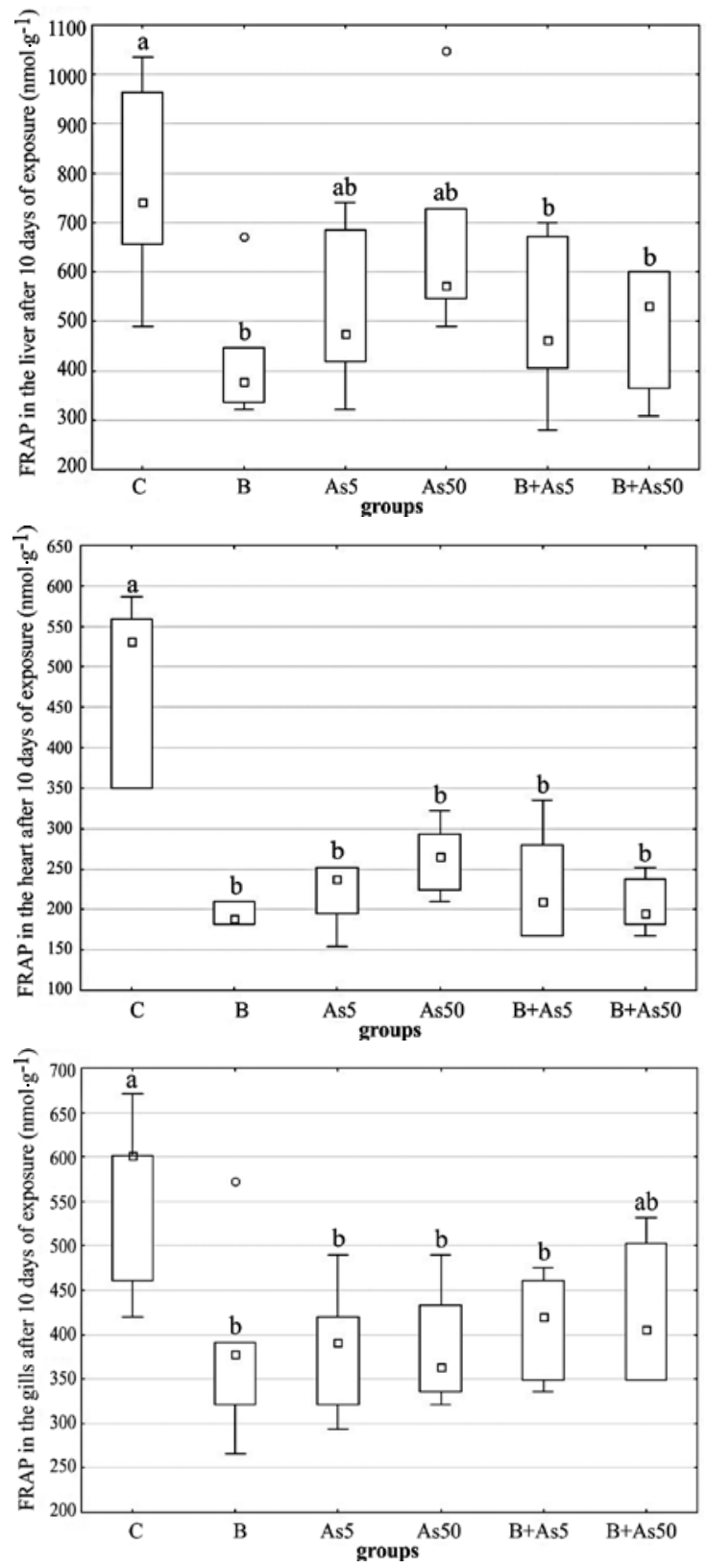

Fig. 1. Effect of combined exposure of arsenic and cyanobacteria on antioxidant activity (ferric reducing antioxidant power [FRAP] $\mathrm{mmol} \cdot \mathrm{g}^{-1}$ ). Box includes the $25^{\text {th }}$ to $75^{\text {th }}$ percentiles, with the mid-point representing the median and the spots showing the extremes. Groups marked with the same letter are non-significantly different $(P<0.05)$.

$\mathrm{C}$ - control group; B - 3\% lyophilised toxic cyanobacterial biomass; As5 - arsenic at $5 \mathrm{mg} \cdot \mathrm{kg}^{-1}, \mathrm{As} 50$ - arsenic at $50 \mathrm{mg} \cdot \mathrm{kg}^{-1} ; \mathrm{B}+\mathrm{As} 5$ and B + As 50 - combinations of cyanobacterial biomass and arsenic. and individual organs (heart, gills and liver) were dissected for the evaluation of oxidative stress indicators. All experiments were performed in compliance with Czech laws for the protection of animals against cruelty (Act No 246/1992 and amendments), as approved by the Ethics Committee of the University of Veterinary and Pharmaceutical Sciences, Brno, Czech Republic.

Separated organs were homogenised as follows: phosphate buffered saline $\mathrm{pH} 7.4$ was added to the tissue sample at a rate of $1 \mathrm{ml}$ per $100 \mathrm{mg}$ of tissue, whereupon it was mechanically mixed for one minute at 8000 revolutions per minute using an UltraTurrax mill (Ika Werke, Staufen, Germany).

The total content of low molecular weight antioxidants was determined by assessing ferric reducing antioxidant power (FRAP) using the spectrophotometric method (absorbance $593 \mathrm{~nm}$ ) of Pohanka et al. (2009). The marker malondialdehyde, a product of membrane oxidative degradation was determined by assessing contents of thiobarbituric acid reactive substances (TBARS), using the spectrophotometric procedure (absorbance $532 \mathrm{~nm}$ ) of Pohanka (2014). Glutathione reductase (GR) is an antioxidant enzyme that produces reduced glutathione in its oxidised form. The GR enzyme activity was measured (absorbance $340 \mathrm{~nm})$ using an adapted optic test (Pohanka et al. 2011).

Results from different treatment groups were compared by one-way analysis of variance (ANOVA) and post hoc analysis of means using Scheffe test. All statistical analyses were performed using Statistica for Windows ${ }^{\circledR} 7.0$ (StatSoft, Tulsa, OK, USA).

\section{Results}

Oxidative stress analysis revealed a significant decrease in FRAP at $\mathrm{T} 10$ in all tissues analysed, especially in groups exposed to cyanobacteria (Fig. 1; Table 1). On the other hand, we observed a significant increase in TBARS at T20 and T30 for heart samples following exposure to higher concentration of cyanobacteria and arsenic combined (Group B + As50), and a significant increase in the liver at T10 after exposure to cyanobacteria (Group B; Fig. 

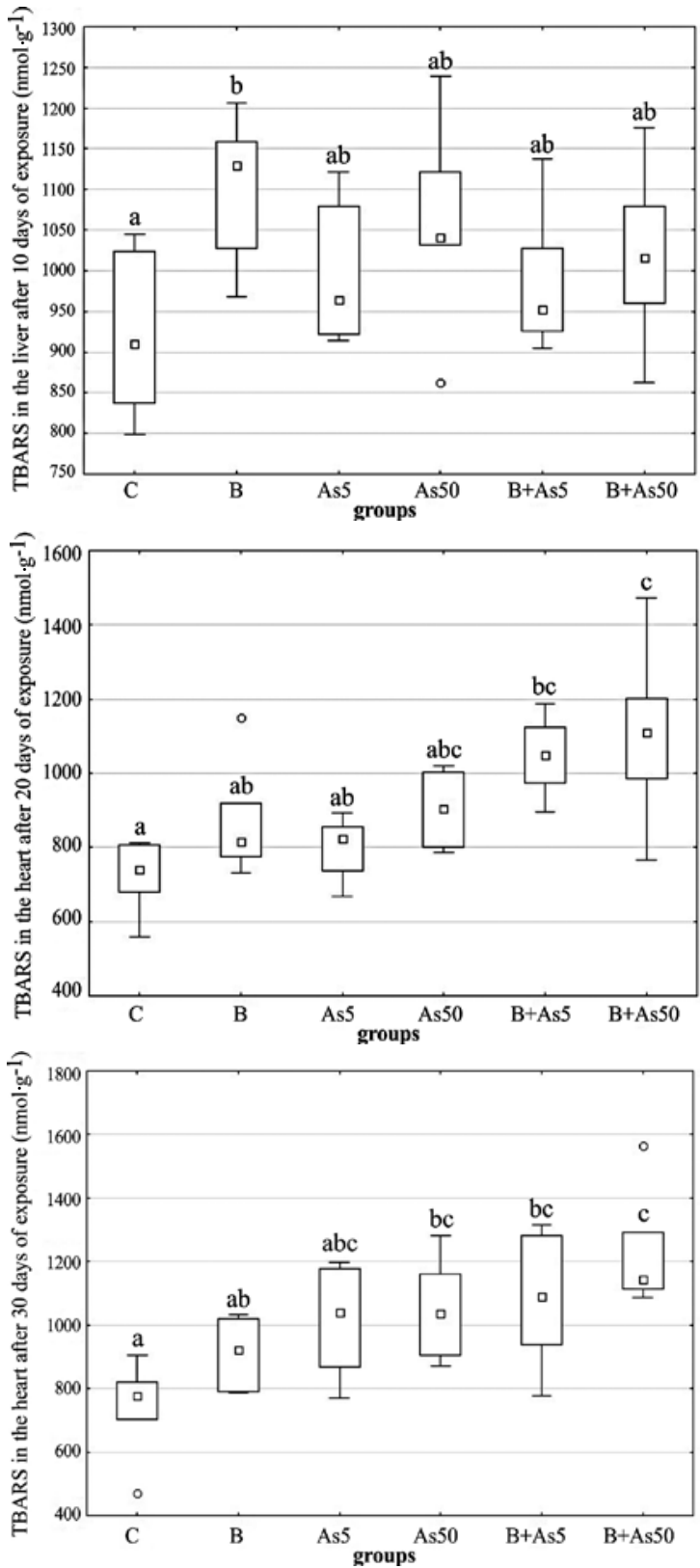

Fig. 2. Effect of combined exposure of arsenic and cyanobacteria on lipid peroxidation (thiobarbituric acid reactive substances [TBARS] $\left.\mathrm{mmol} \cdot \mathrm{g}^{-1}\right)$. Box includes the $25^{\text {th }}$ to $75^{\text {th }}$ percentiles, with the mid-point representing the median and the spots showing the extremes. Groups marked with the same letter are non-significantly different $(P<0.05)$.

C - control group; B - 3\% lyophilised toxic cyanobacterial biomass; As5 - arsenic at $5 \mathrm{mg} \cdot \mathrm{kg}^{-1} ;$ As 50 - arsenic at $50 \mathrm{mg} \cdot \mathrm{kg}^{-1} ; \mathrm{B}+\mathrm{As} 5$ and $\mathrm{B}+$ As50 - combinations of cyanobacterial biomass and arsenic.
2; Table 1). Antioxidant enzyme analysis indicated increased GR in liver at T20 following exposure to higher concentration of cyanobacteria and arsenic combined (Group B + As50), while liver samples exposed to cyanobacteria alone (Group B) showed significantly higher GR at T30 (Fig. 3 ; Table 1). In gills, however, GR was significantly decreased at T10 following exposure to a higher concentration of cyanobacteria and arsenic combined (Group B + As50; Fig. 3; Table 1). All other changes in oxidative stress indicators were either non-significantly increased or decreased in comparison with the control (Table 1).

\section{Discussion}

Ferric reducing antioxidant power (FRAP) is a non-specific test that measures ferric-to-ferrous iron reduction in the presence of antioxidants. As such, FRAP represents the antioxidant power of the tissue sample, generally mediated through non-protein antioxidants.

In the past, FRAP has been used to determine antioxidant-capacity changes due to the actions of natural pigments, drugs and other foreign agents (Pohanka et al. 2011; Mrkvicova et al. 2016). BruckaJastrzebska et al. (2009) noted that FRAP values in rainbow trout increase with age and decrease when dissolved oxygen levels are high. On the other hand, Dabrowski et al. (2004) reported a significant decline of FRAP in rainbow trout following a decrease in water oxygen saturation levels. While a deoxynivalenol-contaminated diet resulted in a significant decrease in FRAP in plasma piglets after 23 days (Modrá et al. 2013), plasma antioxidant capacity (measured 

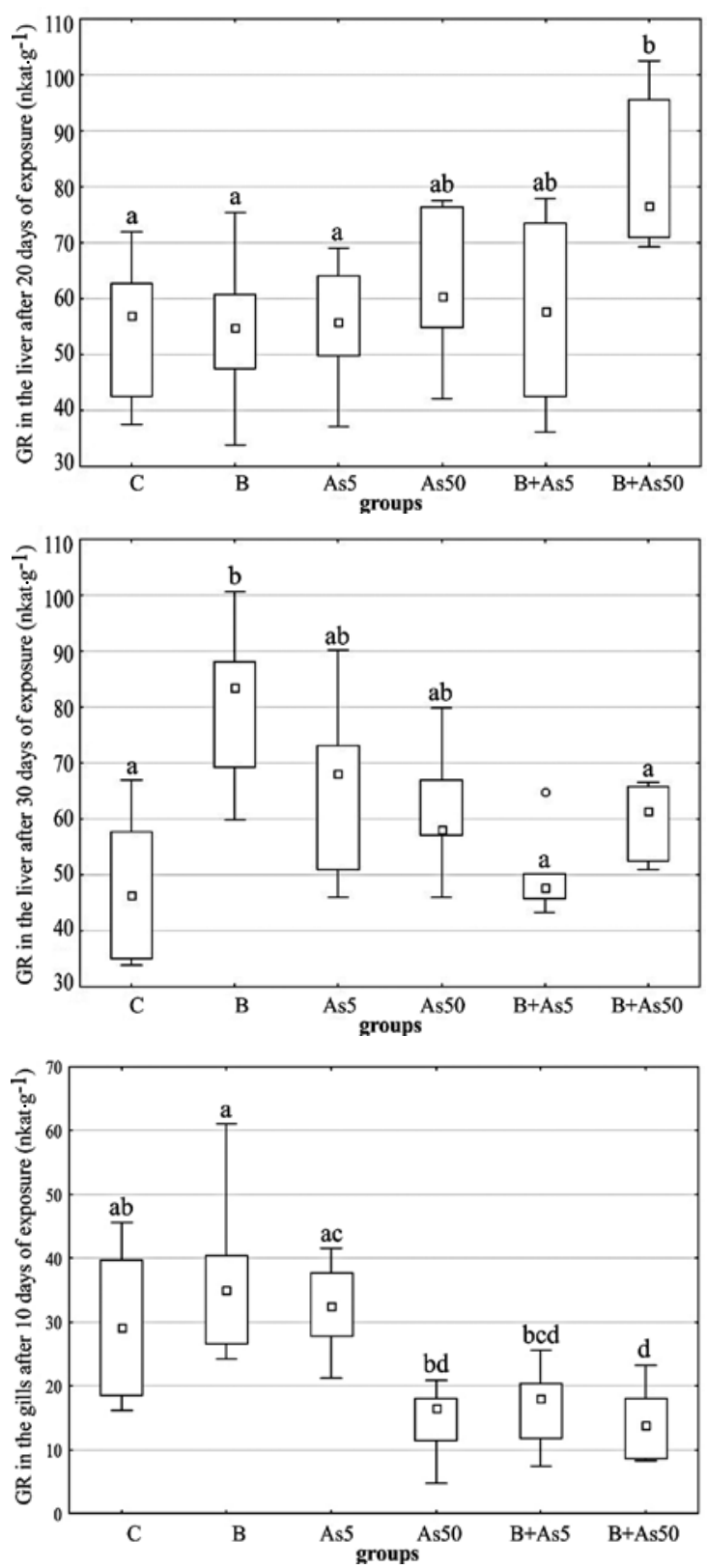

Fig. 3. Effect of combined exposure of arsenic and cyanobacteria on the enzyme activity (glutathione reductase $[\mathrm{GR}] \mathrm{nkat}^{-\mathrm{g}^{-1}}$ ). Box includes the $25^{\text {th }}$ to $75^{\text {th }}$ percentiles, with the mid-point representing the median and spots showing the extremes. Groups marked with the same letter are non-significantly different $(P<0.05)$.

C - control group; B - 3\% lyophilised toxic cyanobacterial biomass; As5 - arsenic at $5 \mathrm{mg} \cdot \mathrm{kg}^{-1} ;$ As 50 - arsenic at $50 \mathrm{mg} \cdot \mathrm{kg}^{-1} ; \mathrm{B}+\mathrm{As} 5$ and B + As50 - combinations of cyanobacterial biomass and arsenic. as FRAP) was unaffected by deoxynivalenol in rainbow trout (Šišperová et al. 2015). Finally, FRAP values were significantly decreased in common carp (Cyprinus carpio) treated with the fungicide prochloraz (Haluzová et al. 2010), as were the liver, gills, digestive system and muscles of sea bream (Sparus aurata) following exposure to Diuron in combination with handling stress (SanchezMuros et al. 2013).

Our own results showed a significant decrease in FRAP values in all the organs examined (liver, heart, and gills) after 10 days of exposure, with no significant changes observed after further 20 and 30 days of exposure (Fig. 1). As significant changes were determined in all experimental groups, this also suggests that both arsenic and microcystin decrease FRAP values, both individually and in combination, but with no evidence of a synergistic effect.

Lipid peroxidation is a freeradical chain-reaction that is primarily the outcome of oxidation and formation of free radicals by peroxides and superoxides continuously generated in living cells exposed to environmental stress. As such, lipid peroxidation is a suitable general mechanism for explaining toxicity of chemicals. Thiobarbituric acid reactive substances (TBARS), which include malondialdehyde and other aldehydes, are produced by lipid peroxidation and can be used as indicators of oxidative stress (Bhattacharya and Bhattacharya 2007; Paskerova et al. 2012).

In animals, the toxicity of arsenic compounds depends on the species, sex and age, dosage and exposure time. Arsenic increases the production of free radicals and 


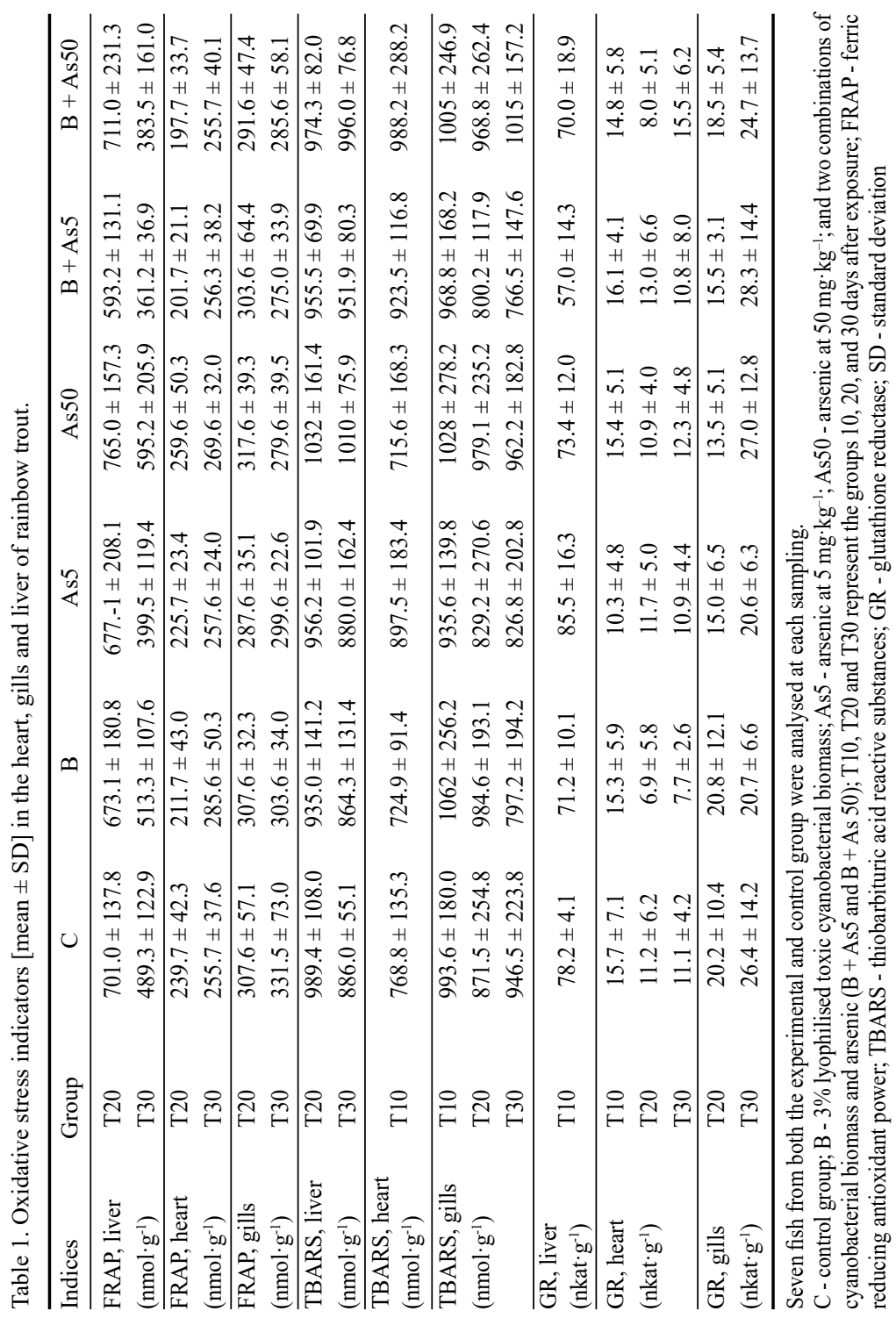

has an impact on all the cellular components, including membranes. Previous studies have shown that the tissues of fish exposed to arsenic at concentrations of $0.1-8.4 \mathrm{mg} \cdot \mathrm{l}^{-1}$ display oxidative stress. Allen et al. (2004b) reported that while arsenite induced lipid peroxidation in the liver, kidney and gills of snakehead fish (Channa punctatus) following a seven-day exposure, TBARS decreased after 60 days of exposure but increased again after 90 days. Arsenic exposure in Indian catfish (Clarias batrachus) increased the TBARS content in liver from the beginning of exposure, with a first peak on day 2, gradually decreasing to the basal level on day 5, and a second peak on day 7, subsiding by day 10 (Bhattacharya and Bhattacharya 2007). Malondialdehyde concentrations were found to have increased 
in the eye, brain, liver, kidney, skin and intestinal tissues of mirror carp after a month of arsenic exposure (Altikat et al. 2013). On the other hand, no significant change in TBARS was observed under the influence of arsenic in the tissues of fish (Bagnyukova et al. 2007).

Lipid peroxidation, therefore, appears to be a reasonable marker of oxidative damage in fish, especially following a short acute exposure to microcystins, complex cell samples and cyanobacterial extracts (Paskerova et al. 2012). The liver, kidneys and gills of fish exposed to microcystins or toxic cyanobacterial cells showed a significant increase in the level of lipid peroxidation after 3, 4, 7 and 21 days (Jos et al. 2005; Atencio et al. 2009). On the other hand, there were no changes in malondialdehyde in any of the organs after 14 days (Jos et al. 2005). No effects were recorded in the liver of silver carp (Hypophthalmichthys molitrix) after a 25-day exposure to toxic cyanobacteria (Blaha et al. 2004). After a 24-h acute exposure to microcystin, the TBARS content increased in the brain of pepper cory (Corydoras paleatus) and decreased in the gills and liver (Cazenave et al. 2006).

Our own results showed an increase in TBARS in the liver after 10 days of exposure; though a significant difference was only documented between the control and cyanobacterial biomass (Group B). As shown above, the majority of previous studies have reported an increase in the TBARS content in a range of organs (mainly liver) following exposure to arsenic or toxic cyanobacteria. Although the liver is the main detoxifying organ in fish, and as such has a high antioxidant capacity, our results showed no change following co-exposure of arsenic and toxic cyanobacteria. In our study, significant differences between the control and both combined stressor groups (Groups B + As5 and As50) were detected in the heart after 20 and 30 days of exposure. While the heart is a rarely studied organ with regard to the detection of oxidative stress markers, our study showed it to be a suitable organ for monitoring lipid peroxidation.

Glutathione reductase (GR) plays an important role in the cellular antioxidant protection and adjustment processes in metabolic pathways. Exposure to low concentrations of arsenic, a decrease in the GR activity was reported in the tissues of fish (Battacharya and Battacharya, 2007; Altikat et al. 2013). In aquatic organisms, such a decrease in GR activity following arsenic exposure is an indicator of oxidative deterioration (VenturaLima et al. 2011). Allen and Rana (2004a) and Sarkar et al. (2014) both reported that the GR activity was significantly affected by arsenic in fish during a 90-day exposure, but that the GR values in the liver, kidney and brain fluctuated. On the other hand, no significant change in the GR activity was observed by Bagnyukova et al. (2007) in the liver of gold fish. In general, therefore, short-term exposure to low arsenic concentrations increases the activity of these enzymes, while chronic exposure usually decreases activity (Shi et al. 2004).

Our data showed a significant increase in the GR activity in the liver of trout exposed to microcystin or cyanobacterial biomass. Similar significant increases in the liver GR enzyme activity have been observed in tilapia (Jos et al. 2005; Atencio et al. 2009), common carp (Adamovský et al. 2007) and pepper cory (Cazenave et al. 2006). A number of experimental investigations, however, have shown no effect on the GR activity in the liver of fish (e.g. Amand o et al. 2011). Hence, GR is a relatively sensitive biomarker of cyanobacteria-induced oxidative stress, especially following long-term exposure and in studies of liver tissue, where, to our knowledge, no inhibition has been recorded, thus indicating the discriminating potential of GR (Paskerova et al. 2012).

Our results correspond with those of previous authors who found the liver to be the most sensitive organ (see above), displaying increased GR activity after 20 and 30 days of exposure. Significant differences were only recorded within the groups with cyanobacterial biomass (Group B), however, and those with higher concentrations of arsenic and cyanobacterial biomass combined (Group B + As50; Fig. 3). On the other hand, the GR 
activity decreased significantly in the gills after 10 days of exposure to high concentrations of arsenic and cyanobacteria combined (Group B + As50). Most previous authors have suggested that the gills are not sensitive enough for the detection of oxidative stress caused by arsenic or cyanobacteria (e.g. Jos et al. 2005). To our knowledge, induction has not been recorded in previous studies on gill tissue, although studies by Min et al. (2015) and Cazenave et al. (2006) did detect a significant decrease in the gill GR activity in the presence of arsenic or cyanobacteria. Our results have shown that combined exposure to arsenic and cyanobacteria can reduce (reverse) the decrease in GR in gills.

These results provide an important insight into the combined effects of two stressors that commonly co-occur in the freshwater environment (i.e. arsenic and Microcystis from cyanobacteria), and the oxidative stress response they elicit in rainbow trout. Some experimental studies have shown that combined stressors can enhance the influence of oxidative stress markers in fish (Adeyemi et al. 2014; Sinha et al. 2015); whereas other studies (e.g. Ransberry et al. 2016) have shown no effect of combined stressors on biomarkers. As fish are the most diverse of vertebrates, high interspecific variability in any biological response is likely, especially as the effect of such biomarkers will depend on type of exposure, material, duration, dose, age, organ and species, as well as many external environmental factors; though these are only rarely characterised. As such, nonsystematic responses make interpretation of oxidative stress biomarkers complicated. Our results confirm the hypothesis that the influence of toxic cyanobacterial biomass and a chemical agent, represented by arsenic, can combine to enhance their harmful effects on rainbow trout, i.e. while single agents in sub-lethal doses change oxidative stress indicators, co-exposure leads to an increased effect, resulting in a significant increase or decrease in levels of FRAP, TBARS and GR activity.

\section{Acknowledgements}

This work was supported by a research project of the National Agency for Agricultural Research of the Czech Republic (QJ1510077) and by IGA VFU Brno (project 220/2016/FVHE). We thank Kevin F. Roche from Academy of Sciences of the Czech Republic for manuscript improvement and English correction.

\section{References}

Adamovský O, Kopp R, Hilscherová K, Babica P, Palíková M, Pašková V, Navrátil S, Bláha L 2007: Microcystin kinetics (bioaccumulation, elimination) and biochemical responses in common carp and silver carp exposed to toxic cyanobacterial blooms. Environ Toxicol Chem 26: 2687-2693

Adeyemi JA, Adewale OO, Oguma AY 2014: Mortality, oxidative stress and hepatotoxicity in juvenile African catfish, Clarias gariepinus Burchell, exposed to lead and cypermethrin. Bull Environ Contam Toxicol 92: $529-533$

Allen T, Rana S 2004a: Effect of arsenic (As $\left.{ }^{\mathrm{III}}\right)$ on glutathione-dependent enzymes in liver and kidney of the freshwater fish Channa punctatus. Biol Trace Elem Res 100: 39-48

Allen T, Singhal R, Rana S 2004b: Resistance to oxidative stress in a freshwater fish Channa punctatus after exposure to inorganic arsenic. Biol Trace Elem Res 98: 63-72

Altikat S, Uysal K, Kuru HI 2013: Analysis of bioaccumulation of arsenic in the brain and eye tissues of mirror carp (Cyprinus carpio carpio) and its effects on various biochemical parametres. J Environ Prot Ecol 14, No 3A: 1225-1235

Amando LL, Garcia ML, Ramos PB, Yunes JS, Monserrat JS 2011: Influence of a toxic Microcystis aeruginosa strain on glutathione synthesis and glutathione-S-transferase activity in common carp Cyprinus carpio (Teleostei: Cyprinidae). Arch Environ Contam Toxicol 60: 319-326

APHA 1998: Standard Methods for the Examination of Water and Wastewater. 20 ${ }^{\text {th }}$ edition. Washington, DC: American Public Health Association

Atencio L, Moreno I, Jos A, Prieto AI, Moyano R, Blanco A, Camean AM 2009: Effects of dietary selenium on the oxidative stress and pathological changes in tilapia (Oreochromis niloticus) exposed to a microcystinproducing cyanobacterial water bloom. Toxicon 53: 269-282

Bagnyukova TV, Luzhna LI, Pogribny IP, Lushchak VI 2007: Oxidative stress and antioxidant defenses in goldfish liver in response to short-term exposure to arsenite. Environ Mol Mutagen 48: 658-665 
Bhattacharya A, Bhattacharya S 2007: Induction of oxidative stress by as in Clarias batrachus: involvement of peroxissomes. Ecotoxicol Environ Saf 66: 178-187

Blaha L, Kopp R, Simkova K, Mares J 2004: Oxidative stress biomarkers are modulated in silver carp (Hypophthalmichthys molitrix Val.) exposed to microcystin-producing cyanobacterial water bloom. Acta Vet Brno 73: 477-482

Brucka-Jastrzębska E, Kawczuga D, Grzelak A, Bartosz G 2009: Magnesium content, total antioxidant status and lipid peroxidation in rainbow trout (Oncorhynchus mykiss Walbaum). Magnesium Res 22: 273-279

Cazenave J, Bistoni MA, Pesce SF, Wunderlin DA 2006: Differential detoxification and antioxidant response in diverse organs of Corydoras paleatus experimentally exposed to microcystin-RR. Aquat Toxicol 76: 1-12

Celechovska O, Harkabusova V, Macharackova B, Vitoulova E, Lavickova A 2011: Accumulation of arsenic during the growing period of rainbow trout (Oncorhynchus mykiss). Acta Vet Brno 80: 219-225

Cerbin S, Kraak MHS, de Voogt P, Visser PM, Van Donk E 2010: Combined and single effects of pesticide carbaryl and toxic Microcystis aeruginosa on the life history of Daphnia pulicaria. Hydrobiologia 643: 129-138

Dabrowski K, Lee KJ, Guz L, Verlhac V, Gabadaun J 2004: Effects of dietary ascorbic acid on oxygen stress (hypoxia or hyperoxia), growth and tissue vitamin concentrations in juvenile rainbow trout (Oncorhynchus mykiss). Aquaculture 233: 382-392

De Coninck DIM, Janssen CR, De Schamphelaere KAC 2013: An investigation of the inter-clonal variation of the interactive effects of cadmium and Microcystis aeruginosa on the reproductive performance of Daphnia magna Aqua Toxicol 140-141: 425-431

Ghosh D, Bhattacharya S, Mazumder S 2006: Perturbations in the catfish immune responses by arsenic: Organ and cell specific effects. Comp Biochem Physiol C Toxicol Pharmacol 143: 455-463

Haluzova I, Modra H, Blahova J, Marsalek P, Siroka Z, Groch L, Svobodova Z 2010: Effects of subchronic exposure to Spartakus (prochloraz) on common carp Cyprinus carpio. Neuro Endocrinol Lett 31 Suppl 2: 105-113

Jos A, Pichardo S, Prieto AI, Repetto G, Vazquez CM, Moreno I, Camean AM 2005: Toxic cyanobacterial cells containing microcystins induce oxidative stress in exposed tilapia fish (Oreochromis sp.) under laboratory conditions. Aquat Toxicol 72: 261-271

Kohoutek J, Adamovský O, Oravec M, Šimek Z, Palíková M, Kopp R, Bláha L 2010: LC-MS analyses of microcystins in fish tissues overestimate toxin levels critical comparison with LC-MS/MS. Anal Bioanal Chem 398: $1231-1237$

Lavanya S, Ramesh M, Kavitha C, Malarvizhi A 2011: Hematological, biochemical and ionoregulatory responses of Indian major carp Catla catla during chronic sublethal exposure to inorganic arsenic. Chemosphere 82: 977-985

Malbrouck C, Kestemont P 2006: Effects of microcystin on fish. Environ Toxicol Chem 25: 72-86

Modra H, Blahova J, Marsalek P, Banoch T, Fictum P, Svoboda M 2013: The effects of mycotoxin deoxynivalenol (DON) on haematological and biochemical parameters and selected parameters of oxidative stress in piglets. Neuro Endocrinol Lett 34: 84-89

Mrkvicova E, Pavlata L, Karasek F, Stastnik O, Dolezalova E, Trojan V, Vyhnanek T, Hrivna L, Holeksova V, Mares J, Brabec T, Horky P, Ruttkay-Nedecky B, Adam V, Kizek R 2016: The influence of feeding purple wheat with higher content of anthocyanins on antioxidant status and selected enzyme activity of animals. Acta Vet Brno 85: 371-376

Paskerova H, Hilscherova K, Blaha L 2012: Oxidative stress and detoxification biomarker responses in aquatic freshwater vertebrates exposed to microcystins and cyanobacterial biomass. Environ Sci Pollut Res 19: 2024-2037

Pohanka M 2014: Caffeine alters oxidative homeostasis in the body of BALB/c mice. Brat Med J 115: 699-703

Pohanka M, Bandouchova H, Sobotka J, Sedlackova J, Soukupova I, Pikula J 2009: Ferric reducing antioxidant power and square wave voltammetry for assay of low molecular weight antioxidants in blood plasma: performance and comparison of methods. Sensors 9: 9094-9103

Pohanka M, Sobotka J, Svobodova H, Stetina R 2011: Investigation of oxidative stress in blood, brain, kidney, and liver after oxime antidote HI-6 application in a mouse experimental model. Drug Chem Toxicol 34: 255-260

Ransberry VE, Blewett TA, McClelland GB 2016: The oxidative stress response in freshwater-acclimated killifish (Fundulus heteroclitus) to acute copper and hypoxia exposure. Comp Biochem Physiol C 179: 11-18

Sánchez-Muros MJ, Villacreces S, Miranda-de la Lama G, de Haro C, García-Barroso F 2013: Effects of chemical and handling exposure on fatty acids, oxidative stress and morphological welfare indicators in gilt-head sea bream (Sparus aurata). Fish Physiol Biochem 39: 581-591

Sarkar S, Mukherjee S, Chattopadhyay A, Bhattacharya S 2014: Low dose of arsenic trioxide triggers oxidative stress in zebra fish brain: Expression of antioxidant genes. Ecotox Environ Safe 107: 1-8

Sinha AK, AbdElgawad H, Zinta G, Dasan AF, Rasoloniriana R, Asard H, Blust R, De Boeck G 2015: Nutritional status as the key modulator of antioxidant responses induced by high environmental ammonia and salinity stress in European sea bass (Dicentrarchus labrax). PLoS One 10: e0135091 
Sisperova E, Modra H, Zikova A, Kloas W, Blahova J, Matejova I, Zivna D, Svobodova Z 2015: The effect of mycotoxin deoxynivalenol (DON) on the oxidative stress markers in rainbow trout (Oncorhynchus mykiss, Walbaum 1792). J Appl Ichthyol 31: 855-861

Shi H, Shi X, Liu KJ 2004: Oxidative mechanism of arsenic toxicity and carcinogenesis. Mol Cell Biochem 255: 67-78

Ventura-Lima J, Ramos, PB, Fattorini D, Regoli F, Ferraz L, Carvalho LM, Monserrat JM 2011: Accumulation, biotransformation, and biochemical responses after exposure to arsenite and arsenate in the estuarine polychaete Laeonereis acuta (Nereididae). Environ Sci Poll Res 18: 1270-1278 